\title{
49. SYNTHESIS OF THE LEG 41 BIOSTRATIGRAPHY AND PALEONTOLOGY, DEEP SEA DRILLING PROJECT
}

\author{
P. Čepek, Bundesanstalt für Geowissenschaften und Rohstoffe, Hannover, Germany, \\ D. Johnson, Woods Hole Oceanographic Institution, Woods Hole, Massachusetts, \\ V. Krasheninnikov, Geological Institute of the USSR Academy of Sciences, Moscow, USSR, \\ and \\ U. Pflaumann, Geologisch-Paläontologisches Institut und Museum der Universität Kiel, Kiel, Germany
}

\section{INTRODUCTION}

Leg 41 of the Deep Sea Drilling Project was confined to the marginal northeastern part of the Atlantic Ocean, along the continent of Africa (Figure 1). This area of the Atlantic Ocean is a region with a relatively ancient oceanic crust. Holes penetrated sediments of a wide stratigraphic scope-from upper Jurassic to Quaternary in age.

Holes were drilled on different structural elements of the Atlantic Ocean bottom. Two sites are on rises: Sierra Leone Rise (Holes 366 and 366A) and Cape Verde Rise (Hole 368). Two sites are connected with deep-water basins: Cape Verde Basin (Hole 367) and the Morocco basin (Hole 370). Holes 369 and 369A were drilled in shallow sediment depths of the continental slope off Spanish Sahara. All these holes penetrated sediments of different facies types with various groups of fauna and flora-benthic calcareous and agglutinated foraminifers, planktonic foraminifers, Radiolaria, ostracodes, ammonites and aptychi, pelagic crinoids, fish remains, nannoplankton, diatoms, spores and pollen, and calcisphaerulids.

One of the most important scientific tasks of Leg 41 was the investigation of the structure of the sedimentary cover of the eastern Atlantic Ocean. Therefore Holes 366 and 366A, where a complete section of Cenozoic exists, were continuously cored; in Holes 368 , $369,369 \mathrm{~A}$ and 370 some intervals were also continuously cored or frequently sampled.

The different groups of fauna and flora enabled us to correlate biostratigraphic "events" for the late Mesozoic and Cenozoic of the tropical and subtropical area of the northeastern Atlantic Ocean. Nannoplankton of the Mesozoic and Cenozoic have been studied by P. Cepek and D. Bukry; Mesozoic Radiolaria by $\mathrm{H}$. Foreman; Cenozoic Radolaria by D. Johnson; upper Jurassic and Valanginian benthic foraminifera by K. Kuznetsova and I. Seibold; Cretaceous agglutinated foraminifers by V. Krasheninnikov and U. Pflaumann; Cretaceous and Cenozoic planktonic foraminifers by $\mathrm{V}$. Krasheninnikov and $\mathrm{U}$. Pflaumann; diatoms by $\mathrm{H}$. Schrader; calcisphaerulids by $U$. Pflaumann and V. Krasheninnikov; Jurassic aptychi by $\mathrm{O}$. Renz; Cretaceous pollen and spores by I. Kotova; Paleogene pollen and spores by E. Zaklinskaya. Papers of authors listed are published in this volume. The data that we obtained are an essential contribution to our knowledge concerning the Mesozoic and Cenozoic stratigraphy of the northeastern Atlantic Ocean.

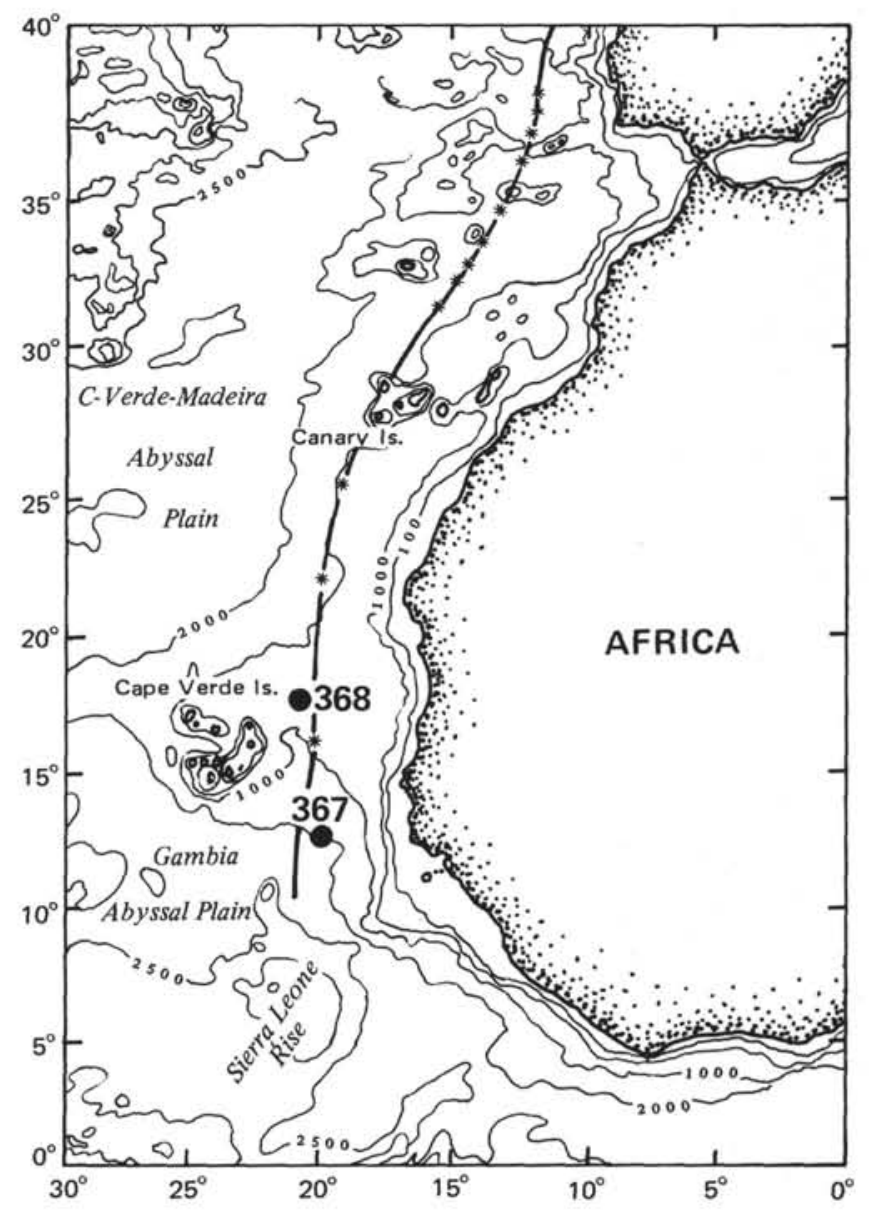

Figure 1. Leg 41 Site location map.

\section{MESOZOIC}

Mesozoic sediments occur in Holes 366, 367, 368, $369 \mathrm{~A}$, and 370 . The most stratigraphically complete section is the succession of upper Jurassic and lower Cretaceous sediments. Due to some gaps in sedimentation and poor microfossil preservation in some parts of sections, more sparse data have been obtained for the Upper Cretaceous sediments.

\section{Oxfordian to Kimmeridgian}

The limestones with porcellanite and cherts of this age from the Cape Verde Basin (Cores 367-32 to 36738) contain rare and poorly preserved assemblages of coccoliths. Benthic foraminifers are also poorly preserved, but relatively rich in number; planktonic 
foraminifers are missing. Partly pyritized Radiolaria are rare to common in Core $367-32$, but are poorly preserved. The aptychi provide a more accurate stratigraphy for this period. Core 367-34 contains aptychi of early Kimmeridgian age. According to O. Renz, the Oxfordian/Kimmeridgian boundary probably occurs somewhere between Sections 367-35-2 and 367-34-4. Cores $367-35$ and $367-36$ could be Oxfordian.

The Oxfordian to Kimmeridgian limestones are the oldest sediments recovered during Leg 41 . Five sites which penetrated different stages of the Cretaceous, were drilled during Leg 14 in nearly the same area. However, the oldest sediments from Leg 14 belong to the Aptian.

\section{Tithonian}

Tithonian limestones were recovered in only a short interval in Core 367-32. Abundant and moderately preserved calcareous nannoplankton and aptychi were used for the age determinations. The total thickness of the upper Jurassic limestones and marlstones at Site 367 is about 70 meters.

\section{Berriasian}

The Berriasian age of limestones and marlstones from the Cape Verde Basin (Cores 367-30 to 367-32) was determined with the help of calcareous nannoplankton, which are rare to common in occurrence and generally of moderate preservation. Foraminifers are missing and radiolarians are generally rare and poorly preserved. Aptychi of Berriasian to Tithonian age were found in Cores 367-30 and 367-31.

\section{Valanginian to Hauterivian}

Sediments of this age were found in two areas-the Cape Verde Basin (Site 367) and Morocco Basin (Site 370 ), where they have different character. At Site 367 the Valanginian sediment is composed of limestones and marlstones. It occurs in Core 370-30 and the age was determined by coccoliths. According to the benthic foraminifers in Cores 370-26 to 370-29, these sediments also belong to the Valanginian but the foraminifers are rare and of poor preservation.

The Hauterivian interval of Site 367 shows the same lithology. Sediments of this age are present in Cores $367-27$ to $367-29$ on the base of presence of common and moderately preserved coccoliths and on the base of aptychi from Cores 367-26 and 367-27. In Core 367-28, aptychi of early Cretaceous age, probably Valanginian, also occur. Foraminifers and radiolarians are rare or missing.

At Site 370 the Valanginian-Hauterivian interval is represented by marlstones, with silty clay, sandstone, claystone, and marl. Planktonic foraminifers are generally rare with poor preservation, benthic ones are rich, coccoliths are generally common with moderate preservation, and radiolarians are absent. Core 370-41 contains a rich assemblage of spores and pollen, dated as Neocomian. Valanginian sediments are the oldest recovered sediments from Site 370 .

The coccoliths made it possible to subdivide the Valanginian-Hauterivian interval at Site 370 into two parts: late Hauterivian in Cores $370-35$ to $370-38$ and late Valanginian to early Hauterivian in Cores $370-38$ to $370-51$ (hole bottom). Cores $370-38$ to $370-49$ were determined as being late Valanginain by using benthic foraminifers.

\section{Barremian}

Barremian sediments occur at Site 367 (Cape Verde Basin, Cores 367-25 to 367-26; limestones and marlstones), and Site 370 (Morocco Basin, Cores 370-33 to 370-35; siltstones). Foraminifers and radiolarians at Site 367 are poorly to moderately preserved with low abundance. Calcareous nannoplankton are common to abundant with good preservation.

\section{Aptian to Middle Albian}

This stratigraphic interval is represented by black shales at Site 367 (Cape Verde Basin) in Cores 367-22 to 367-25; by silty nanno marls Site 369 (continental slope off Spanish Sahara) in Cores 369A 42 to 369A-47 (only early and middle Albian); and by silty clay and silty claystone at Site 370 (Morocco Basin) in Cores 370-27 to 370-32. Generally the foraminifers and nannofossils of the Aptian-middle Albian are abundant with good preservation, but sometimes are rare with poor preservation or they are absent. Spores and pollen were abundant and well preserved in Samples 367-21, CC and 367-23, CC. At Site 370 Samples 370-29, CC to $370-32$, CC yielded well-reserved spores and pollen which belong to assemblages II and III (Kotova, this volume). Pyritized Radiolaria, generally of poor preservation, were found in Cores $367-25$ to $367-28$.

\section{Late Albian to Coniacian}

Black shales of late Albian to Coniacian age were recovered at Site 367 (Cape Verde Basin) partly in Core $367-17$, and in Cores 367-18 to 367-22. Similar shales of late Albian to late Turonian age were observed at Site 368 (Cape Verde Rise) in Cores 368-60, 368-62 and 36863. This black shale facies also occurred in Cores 36857 to $368-59$ but it was only possible to assign a late Cretaceous age to these sediments. At Site 367 foraminifers and coccoliths were partly abundant with moderate to good preservation but usually rare with poor preservation or absent. Samples 367-23, CC and 367-21, CC contain abundant well-preserved pollen and spores assigned to Cenomanian age.

In Cores 369A-41 to 369A-42 (continental slope off Spanish Sahara) the late Albian to Turonian is mostly developed in olive to black marls with well preserved and abundant foraminifers and coccoliths. In the deep basin off Morocco (Cores 370-20 to 370-24) this stratigraphic interval-late Albian to early Cenomanian-is represented by dark greenish-gray claystones and shales which contain well preserved and common to abundant foraminifers, nannos, spores, and pollen.

The sediments of late Albian to Cenomanian age form the only stratigraphic unit which can be practically determined in all Leg 41 sites, except Site 366.

Poor micropaleontological characteristics of the upper part of the black shales unit prevent the precise determination of the lower/upper Cretaceous boundary at Sites 367 and 368. At Site 367 (Cape Verde 
Basin) this boundary can be located between Cores 367 20 and 367-21; in this case the thickness of lower Cretaceous sediments reaches 390 meters. At Site 369 the lower upper Cretaceous boundary is marked by a very pronounced stratigraphic break-late Albian sediments are covered by Santonian-Campanian ones. This boundary is even more sharp at Site 370 (Morocco Basin) where the topmost Albian-basal Cenomanian (the Rotalipora apenninica Zone) is overlain by Paleocene sediments; thickness of lower Cretaceous sediments at this site exceeds 500 meters, though basal layers of lower Cretaceous have not been discovered.

The same paucity of microfauna and flora in upper horizons of the black shale unit accounts for our limited knowledge about the Cenomanian and Turonian stratigraphy. Sediments of this age are definitely present at Sites 367 and 368 (based on nannofossils), but it is very difficult to give detailed subdivision of this interval.

\section{Coniacian to Early Campanian}

This stratigraphic unit is developed on the continental slope off Spanish Sahara (Cores 369A-39 and $369 \mathrm{~A}-40$ ) and is characterized by marlstones and chalk. Age determination is based on well-preserved and abundant foraminifers and coccoliths. Well-preserved but rare Radiolaria were observed in Core 369A-39. The silty clays of Coniacian (partly? Santonian age) were also found at Site 367 (Cape Verde Basin) in Core 367-16 and partly in Core 367-17 with rare and poorly preserved coccoliths.

\section{Late Campanian to Maestrichtian}

Late Campanian to Maestrichtian sediments were definitely identified at Site 366 (only Maestrichtian) and in Hole 369A. On the Sierra Leone Rise (Core 366$55)$, coccoliths and foraminifers with moderate preservation were found in a light olive-gray marlstones of Maestrichtian age. On the continental slope off Spanish Sahara (Hole 369A) the Maestrichtian (Cores 369A-35 to 369A-39) and late Campanian to Maestrichtian (Cores 369A-36 to 369A-39) sediments consist of limestones with porcellanites and cherts and marlstones. These deposits contain relatively rich and moderate to well preserved foraminifers and coccoliths and rare but well-preserved Radiolaria.

It is quite possible that at Site 367 the Maestrichtian sediments constitute a part of noncalcareous variegated clays with agglutinated foraminifers. At Site 368 a member of noncalcareous green silty clays (Cores 36850 to 368-54) with Rzehakina epigona and other agglutinated foraminifers belongs to the CampanianMaestrichtian.

It is very difficult to determine thicknesses of upper Cretaceous sediments in sequences of noncalcareous clays which have sparse microfauna and flora or are barren of fossils, or in sites where there has been discontinuous coring. At Site 367 the thickness of upper Cretaceous sediments can be roughly estimated as 240 meters and at Site 368 as 380 meters. The thickness of calcareous upper Cretaceous sediments of Hole 369A does not exceed 50 meters due to some stratigraphic gaps.

The upper Jurassic and Cretaceous stages determined in the Sites of Legs 14 and 41 are shown on Figure 2.

\begin{tabular}{|c|c|c|c|c|c|c|c|c|c|c|}
\hline $\begin{array}{l}\text { Age } \\
\text { Site }\end{array}$ & 135 & 136 & 137 & 138 & 140 & 366 & 367 & 368 & 369 & 370 \\
\hline Maestrichtian & & & & & & & & & & \\
\hline Campanian & & & & & & & 5 & & & \\
\hline Santonian & & & & & & & & & & \\
\hline Coniacian & & & & & & & & & & \\
\hline Turonian & & & & & & & & & & \\
\hline Cenomanian ${ }^{\circ}$ & & & & & & & & & & \\
\hline Albian & & & | & & & & & & & \\
\hline Aptian & & 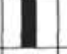 & & & & & & & & \\
\hline Barremian & & & & & & & & & & \\
\hline Hauterivian & & & & & & & & & & \\
\hline Valanginian & & & & & & & & & & \\
\hline Berriasian & & & & & & & & & & \\
\hline Tithonian & & & & & & & & & & \\
\hline Kimmeridgian & & & & & & & & & & \\
\hline Oxfordian & & & & & & & & & & \\
\hline
\end{tabular}

Figure 2. Upper Jurassic and Cretaceous stages determined at sites from Legs 14 and 41.

\section{Cretaceous/Tertiary Boundary}

On the continental slope off Spanish Sahara (Hole 369A) and in the deep basin off Morocco (Site 370) Mesozoic and Cenozoic sediments are separated by hiatuses: in Hole 369A the late Maestrichtian is covered by middle Eocene (the Globorotalia lehneri Zone), in Hole 370 late Albian to early Cenomanian (the Globotruncana apenninica Zone) is overlain by lower Paleocene (the Globorotalia pusilla Zone). It is difficult to determine real time limits of erosional processes or nondeposition.

On the Cape Verde Rise (Site 368) and in the Cape Verde Basin (Site 367) the stratigraphic control was too poor to provide precise information on the character of the Cretaceous/Tertiary boundary. The fossils are partly missing and partly have poor preservation. The sediments were probably deposited below the CCD. The Cretaceous-Paleogene boundary remains obscure here.

On the Sierra Leone Rise (Site 366) the transition from Cretaceous to Tertiary age probably occurred without hiatus. There are no data on this boundary as, due to technical difficulties, this sequence was not sampled. Maestrichtian sediments (the Globotruncana contusa Zone) and Danian sediments (the Globorotalia trinidadensis Zone) are separated by an interval (up to $18 \mathrm{~m}$ ) drilled without coring. It is possible that this interval corresponds to the late Maestrichtian (the Abathomphalus mayaroensis Zone) and the basal Danian with minute Globigerina, and that sedimentation near the Cretaceous/Paleogene boundary was uninterrupted.

\section{CENOZOIC}

Cenozoic sediments have been penetrated by all holes drilled during Leg 41. Abundant planktonic 
foraminifers, nannoplankton, and Radiolaria have been used for the age determination of sediments (Sites $366,368,369,370)$. Some horizons contain also rather numerous benthic foraminifers. However, paleontologic characteristic of clay sediments (Sites 367,368 ) is poor where the age determination is based on occasional findings of these fossils. Site 366 (the Sierra Leone Rise) contains the whole succession of Cenozoic sediments with two small gaps: at the lower middle Miocene and at the middle upper Miocene boundaries.

\section{Paleocene}

A complete Paleocene section of calcareous sediments occurs on the Sierra Leone Rise and is 112 meters thick (Site 366). All foraminiferal and nannoplankton zones have been recognized here. The Danian stage (the Globorotalia trinidadensis Zone) is represented by deep-water pelagic calcareous oozes (19 $\mathrm{m}$ thick) with abundant planktonic foraminifers. Their preservation does not differ from that of Maestrichtian or Paleocene foraminifers. These data do not fit the idea concerning the high position of the CCD in the Danian time in oceanic basins. In the Morocco basin (Site 370) Paleocene is composed of marls and nanno clays (19 $\mathrm{m}$ thick), and its lower part (including the Danian stage) is absent. On the continental slope off Spanish Sahara (Hole 369A) sediments of this age are missing.

In the Cape Verde Basin (Site 367) and on the Cape Verde Rise (Site 368) Paleocene sediment constitutes apparently a part of the sequence of noncalcareous clays, which are barren of fossils or with rare primitive agglutinated foraminifers. Only its uppermost part has been paleontologically determined based on Radiolaria Bekoma bidartensis Zone.

\section{Eocene}

Eocene sediments are very well developed in the northeastern Atlantic and are encountered in all Leg 41 Sites.

In the Sierra Leone Rise calcareous sediments of this age (limestones, clayey limestones, nanno chalk and nanno oozes, marlstones and calcareous clays with numerous interbeds of siliceous limestones and porcellanites) reach 315 meters thick and are characterized by abundant planktonic foraminifers, nannoplankton, and Radiolarians. The latter are especially numerous in the upper Eocene. All three groups of microfossils testify to the stratigraphic completeness of the section. At Site 369 the Eocene is incomplete-24 meters of nanno chalk and limestones of middle Eocene age (the Globorotalia lehneri Zone) is discomformably covered by nanno marls $(5 \mathrm{~m})$ of upper Eocene with abundant radiolarians. At Site 370 Eocene sediment rests on Paleocene sediments with a gap and the lower part of the lower Eocene is missing. Minimal thickness of the Eocene reaches 218 meters, but poor assemblages of planktonic foraminifers and nannoplankton in the calcareous clays and silts prevent precise determination of sediment stratification.

Deep-water sediments of Eocene age consist of noncarbonate or slightly calcareous clays, turbidites, zeolitic clays, and porcellanites with very scarce nannoplankton and planktonic foraminifers and more common radiolarians and diatoms. They permit identification of all subseries of the Eocene at Site 367, but only the lower Eocene has been recognized at Site 368 within a section of clays barren of fossils.

\section{Oligocene}

On the Sierra Leone Rise (Site 366) and on the continental slope off Spanish Sahara (Site 369) calcareous sediments of Oligocene age (nanno chalk and oozes, marls) are connected with the upper Eocene by a gradual transition. All zones of the Oligocene have been identified here based on rich assemblages of planktonic foraminifers, nannoplankton, and radiolarians. Thickness of Oligocene sediments at Site 366 is 159 meters and at Site $369 \mathrm{~A}$ is 181 meters.

Calcareous silty clays of Oligocene age evidently are well developed in the Morocco Basin but because of discontinuous coring only the upper part of Oligocene with planktonic foraminifers (the Globorotalia opima Zone), nannofossils, and radiolarians has been identified.

It is quite possible that a part of clays and turbidites in the Cape Verde Basin (Site 367) and the Cape Verde Rise (Site 368 ) belongs to the Oligocene, considering the total thickness of Paleogene sediment (for instance, it is approximately 400 meters at Site 368 .

\section{Miocene}

On the Sierra Leone Rise (Site 366) and continental slope off Spanish Sahara (Hole 369A) Miocene sediments rest conformably on Oligocene sediments. The Miocene/Oligocene relation is unknown in Sites 367,368 and 370.

Pelagic calcareous sediments (nanno oozes, chalk, and marls) of Miocene age with abundant planktonic foraminifers and nannoplankton have been penetrated at Sites 366 and 369. Siliceous microorganisms are very rich in the lower and middle Miocene but disappear in the upper Miocene. Excellent micropaleontological characteristics enabled the determination of some hiatuses: at the lower/middle and middle/upper Miocene boundaries at Site 366, and within the lower Miocene of Site 369. Thickness of Miocene sediments on the Sierra Leone Rise reaches 173 meters. The same oozes, chalk, and marls occur in the upper and middle Miocene sediments of the Cape Verde Rise (Site 368) but in the lower Miocene they are replaced by clays with sparse fossil remains.

Miocene sediments of the Morocco Basin (Site 370) are rather different. Lower Miocene marls and clays contain abundant radiolarians, diatoms, and sponge spicules; calcareous plankton is sporadic. The middle and upper Miocene sediments are composed of turbidites with heterogeneous microfauna and flora. The same deep-water turbidites with heterogeneous and well-sorted assemblages of microorganisms have been identified in the Miocene sediment of the Cape Verde Basin (Site 367).

\section{Pliocene}

On the Sierra Leone Rise (Site 366), Cape Verde Rise (Site 368), and continental slope off the Spanish Sahara (Site 369) nanno and nanno-foraminiferal oozes and marls of Pliocene age rest conformably on sediments of Miocene age. The most complete section of Pliocene 
sediments has been met on the Sierra Leone Rise where all foraminiferal and nannoplankton zones have been determined; its thickness is about 57 meters. At Site 369 only the lower Pliocene sediments are present. In the Cape Verde Basin (Site 367) the Pliocene section is composed of deep-water, clayey silty turbidites with poor heterogeneous microfauna and flora.

\section{Quaternary}

Sediments of this age are represented by two facies types. In the area of the Sierra Leone Rise (Site 366), Cape Verde Rise (Site 368) and continental slope off Spanish Sahara (Site 369) the Quaternary sediments are soft nanno and nannoforaminiferal oozes and marls. The section of Quaternary sediments at Site 368 is significant because all five foraminiferal subzones have been traced here; minimal thickness is 56 meters, but unfortunately the Quaternary and Pliocene are separated by an uncored interval. The normal Quaternary/Pliocene contact has been observed at Site 366 where Quaternary sediments are about 24 meters thick. On the contrary, a thin layer (1.5) of soft nannoforaminiferal Quaternary oozes at Site 369 occurs unconformably on the lower Pliocene sediments.

In the Cape Verde Basin (Site 367) and Morocco Basin (Site 370 Quaternary sediment is composed of deep-water turbidites-alternation of clays, silts, and marls with heterogeneous assemblages of microfauna and flora.
The results of stratigraphic investigations of Leg 41 are: (1) creation of the stratigraphic scheme of Mesozoic and Cenozoic sediments of the Atlantic Ocean off northwest Africa based on different groups of fauna and flora; (2) clarification of many events of the geological history of the area under consideration; (3) the close similarity of lithological and paleontological patterns of the upper Jurassic and lower Cretaceous sediments of the eastern (Leg 41) and western (Leg 11) margins of the Atlantic Ocean has been outlined; (4) close resemblance of pollen and spores assemblages (land vegetation) of lower Cretaceous with those of South America; (5) significance of calcisphaerulids for stratigraphic subdivision of upper Jurassic and Cretaceous sediments has been confirmed as well as similarity of some calcisphaerulids with those from the Indian Ocean (Leg 27); (6) significance of benthic agglutinated foraminifers for the age determination of deep-water clayey sediments with sparse fossil contents; (7) well-known zonal schemes based on planktonic foraminifers, nannoplankton, and radiolarians have been used for the zonal subdivision of Mesozoic and expecially Cenozoic sediments that proved the great importance of plankton for the worldwide correlation.

Relation of foraminiferal, nannoplankton, and radiolarian zones for Sites $366,368,369$ and 370 are given in Figure 3. 
P. ČEPEK, D. JOHNSON, V. KRASHENINNIKOV, U. PFLAUMANN

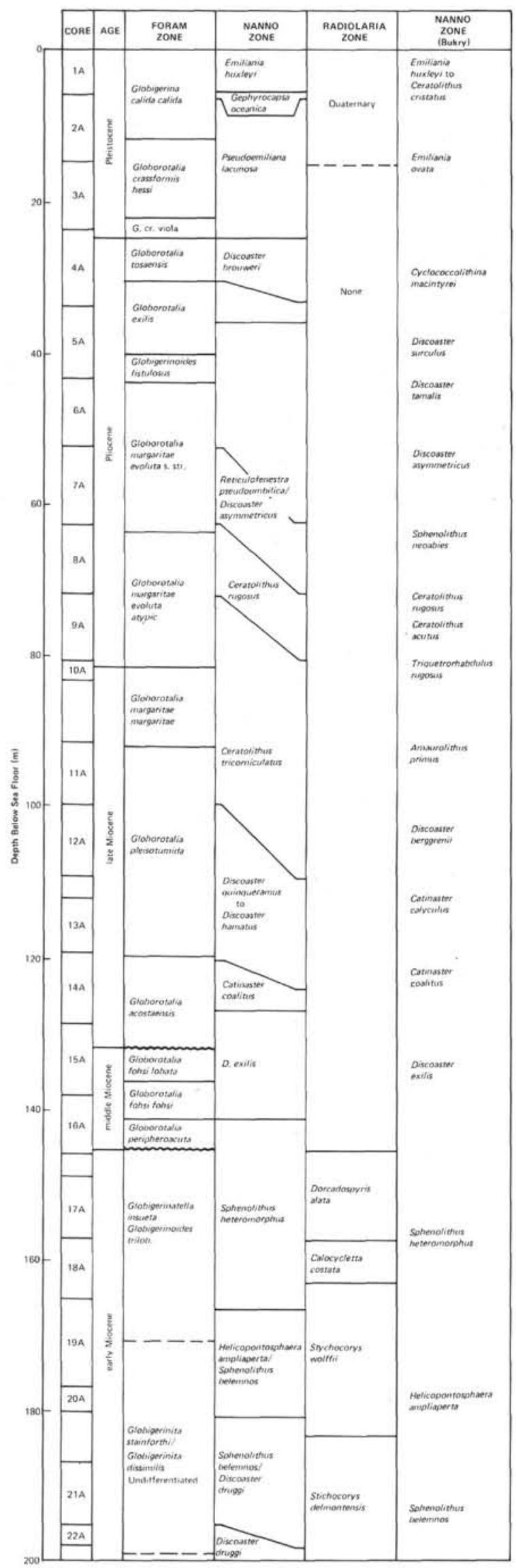

Figure 3. Leg 41 site biostratigraphic zones.

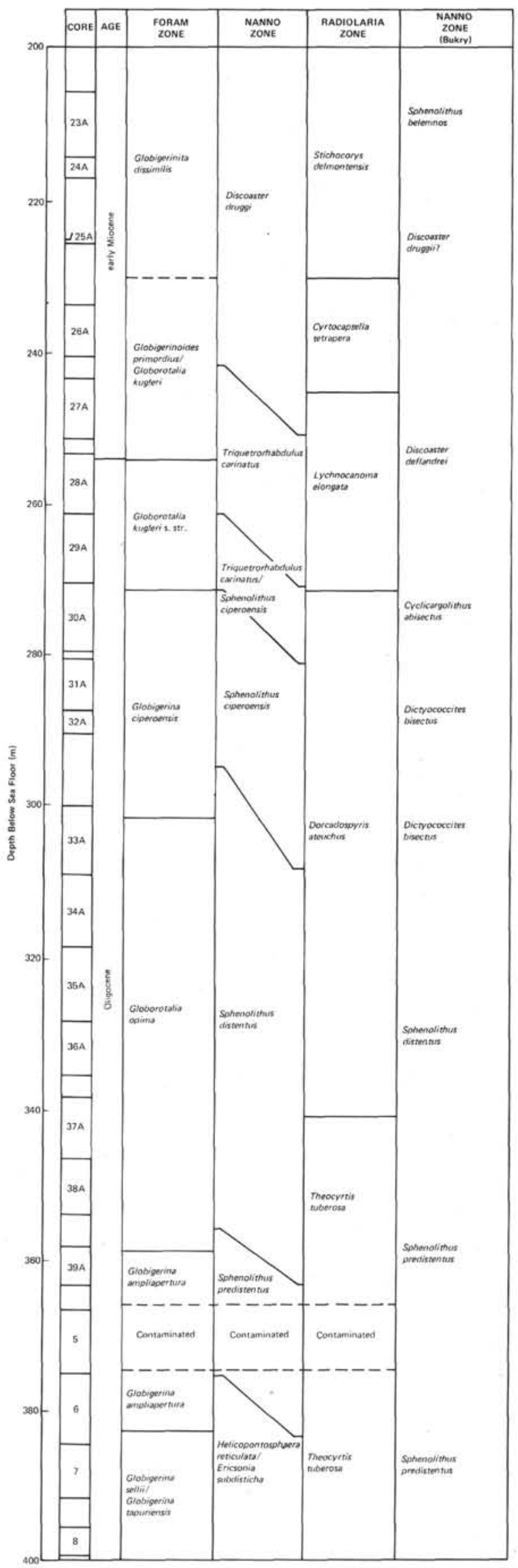

Figure 3. (Continued). 
SYNTHESIS OF BIOSTRATIGRAPHY AND PALEONTOLOGY

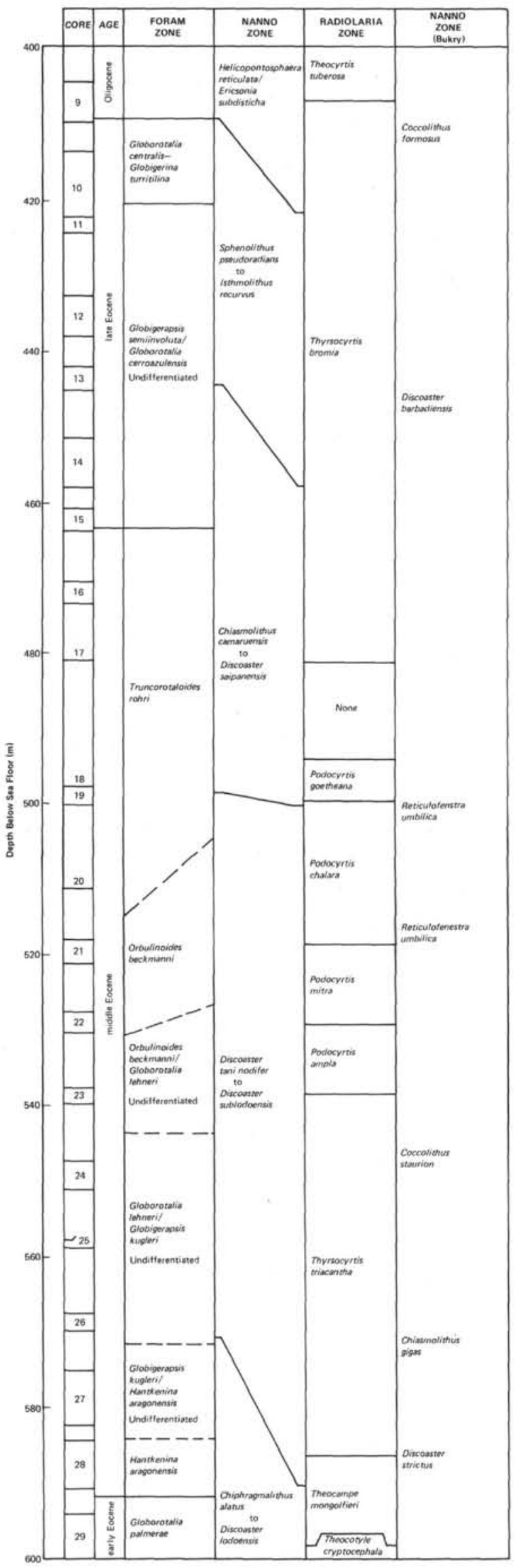

Figure 3. (Continued).

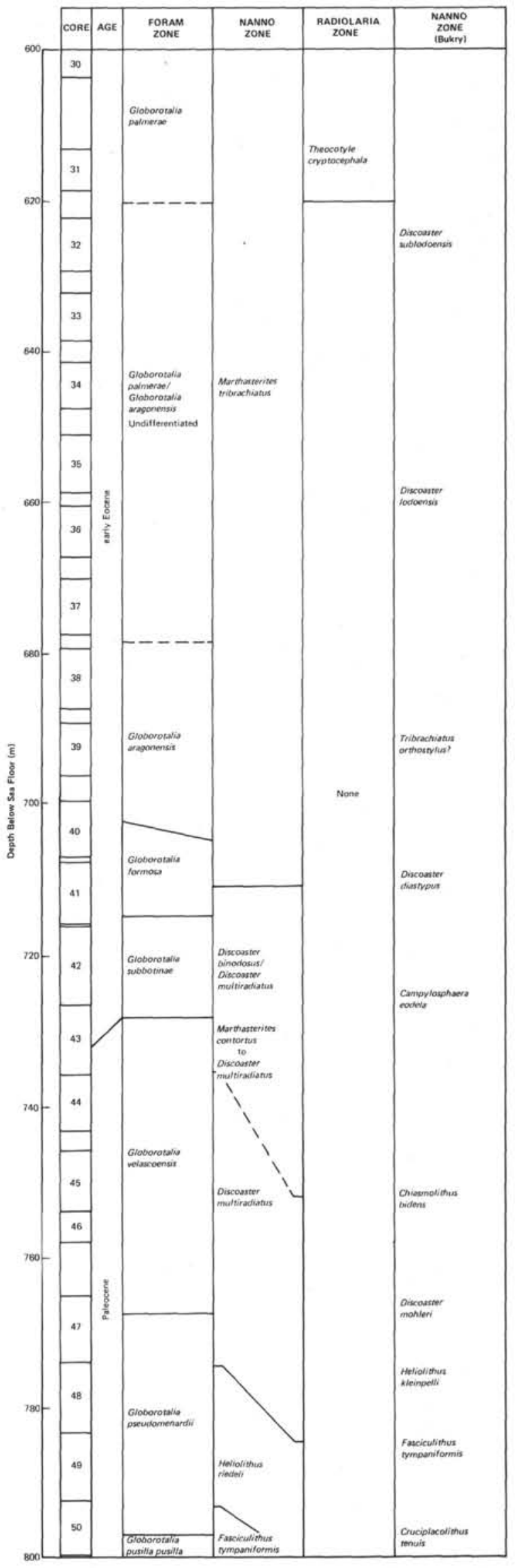

Figure 3. (Continued). 


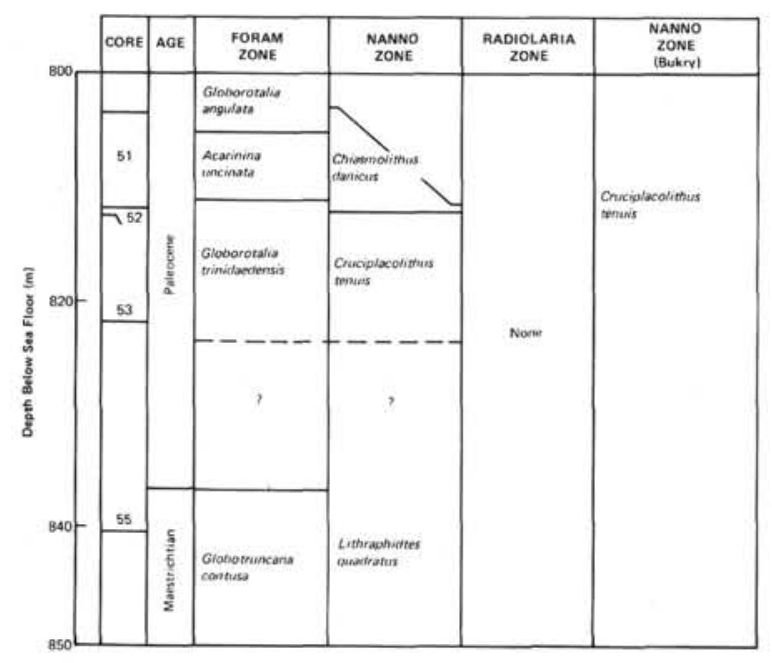

Figure 3. (Continued).

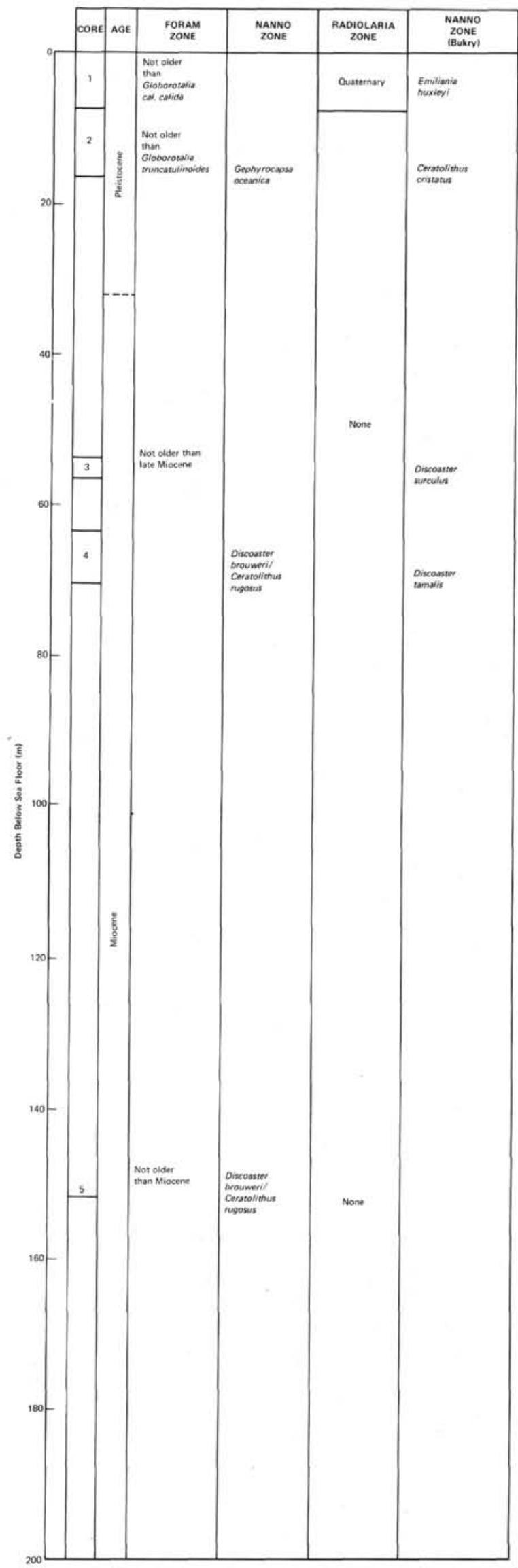

Figure 3. (Continued). 


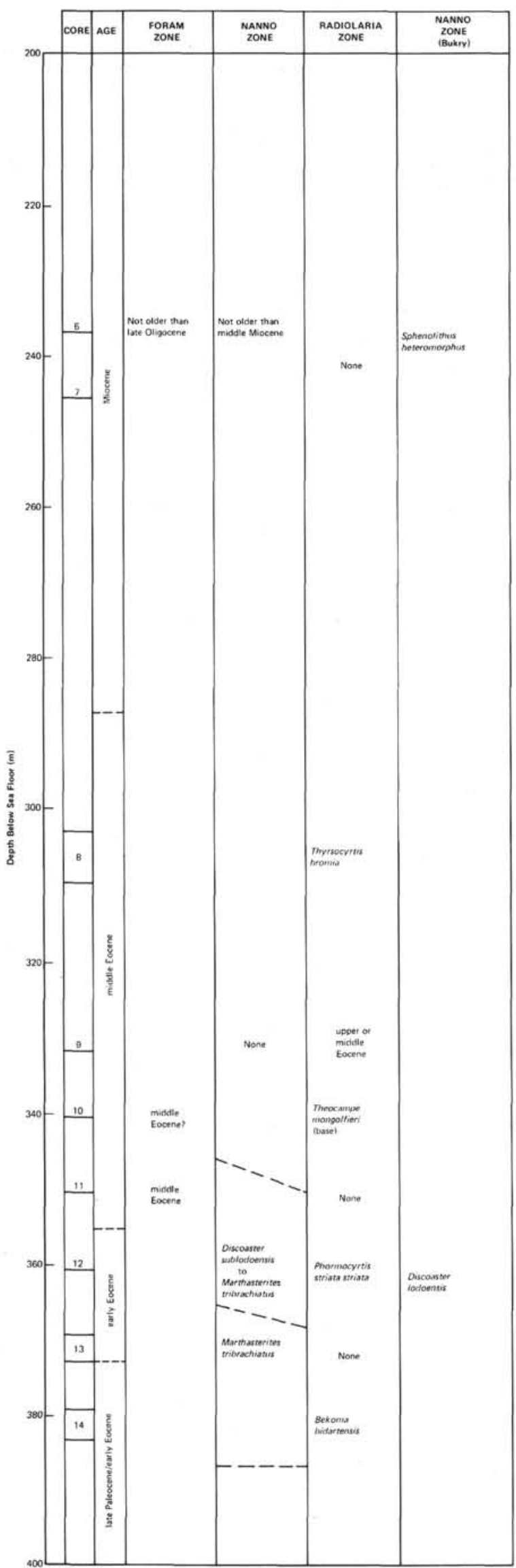

Figure 3. (Continued).

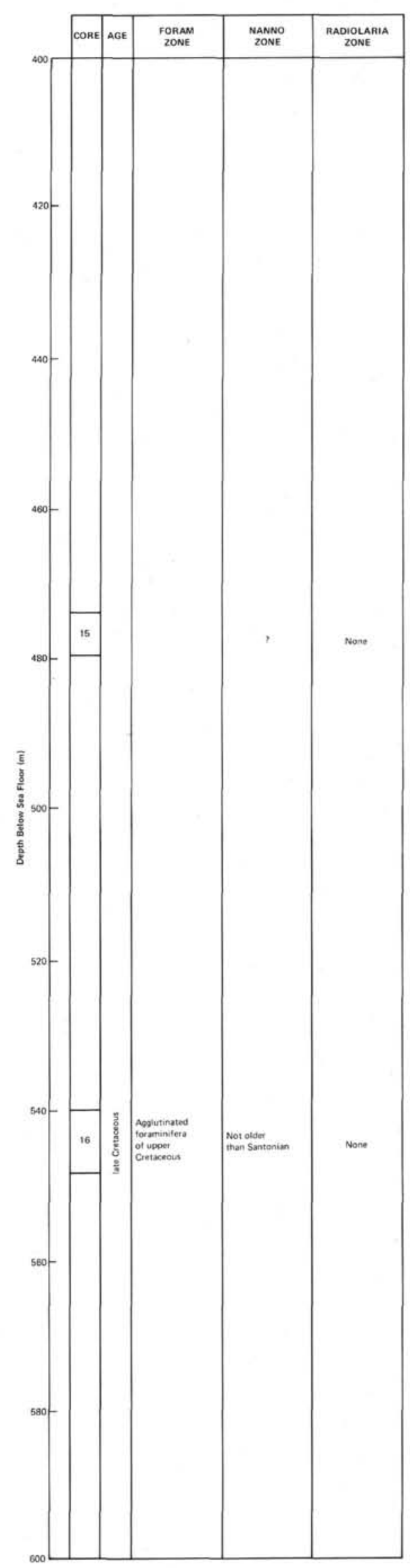

Figure 3. (Continued). 
P. ČEPEK, D. JOHNSON, V. KRASHENINNIKOV, U. PFLAUMANN

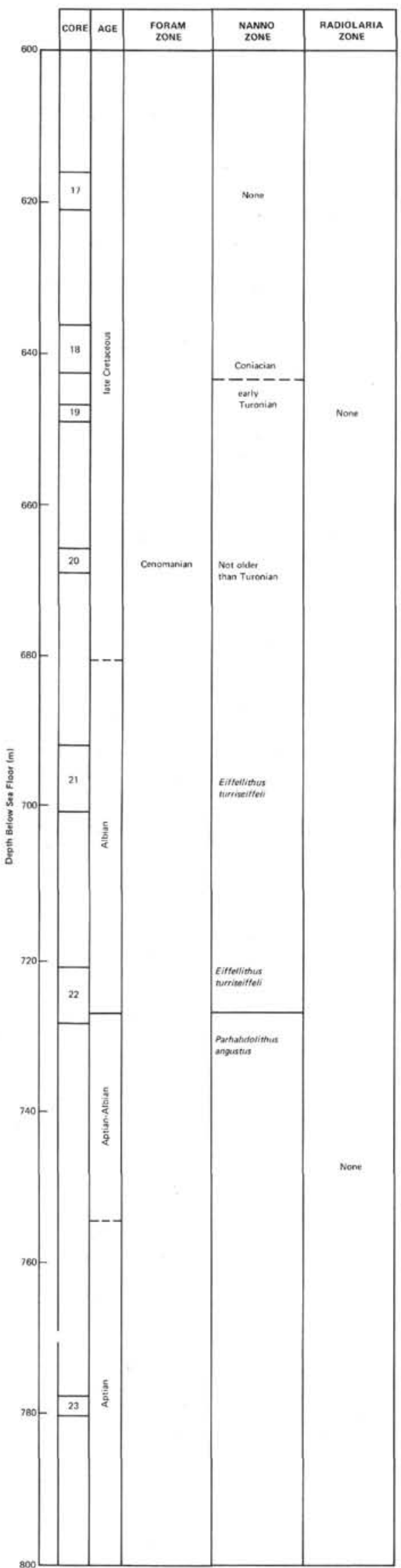

Figure 3. (Continued).

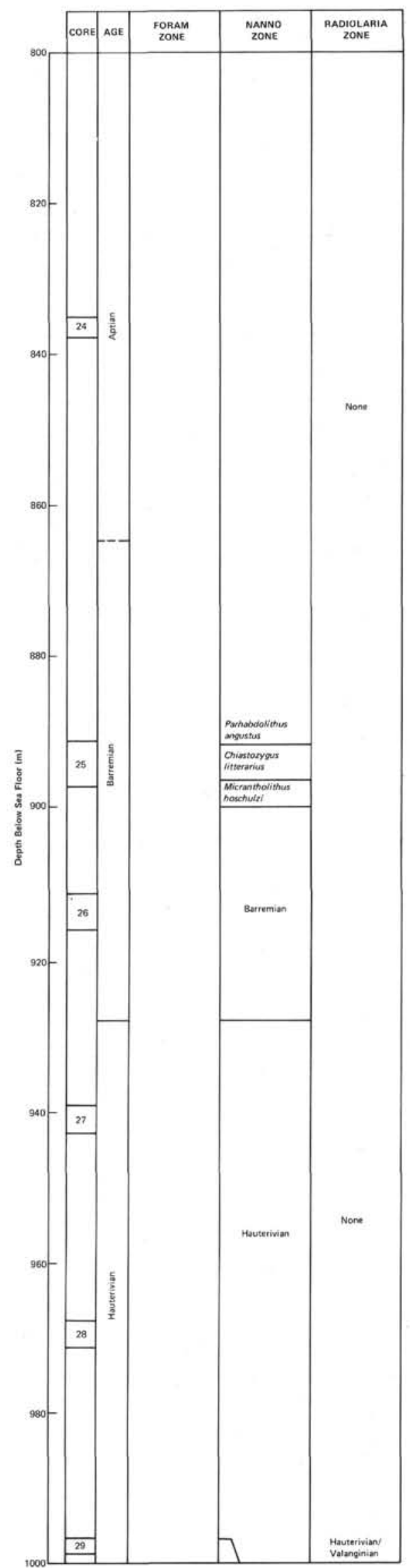

Figure 3. (Continued). 


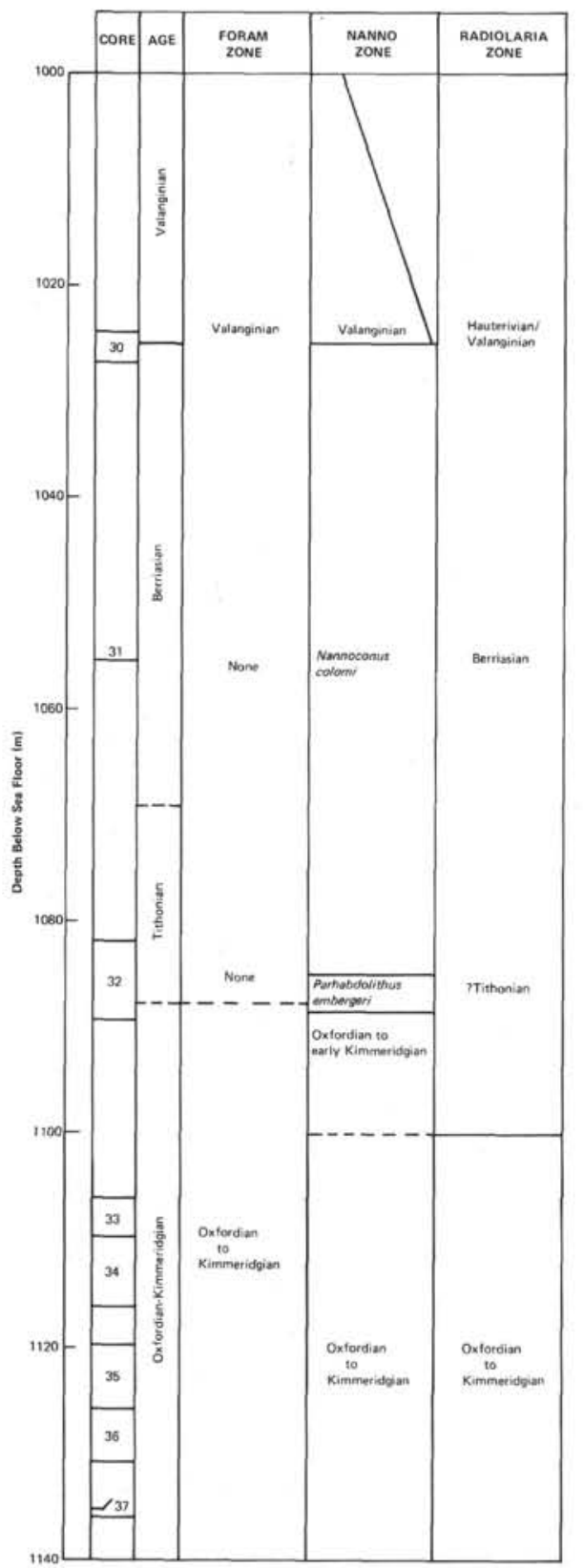

Figure 3. (Continued).

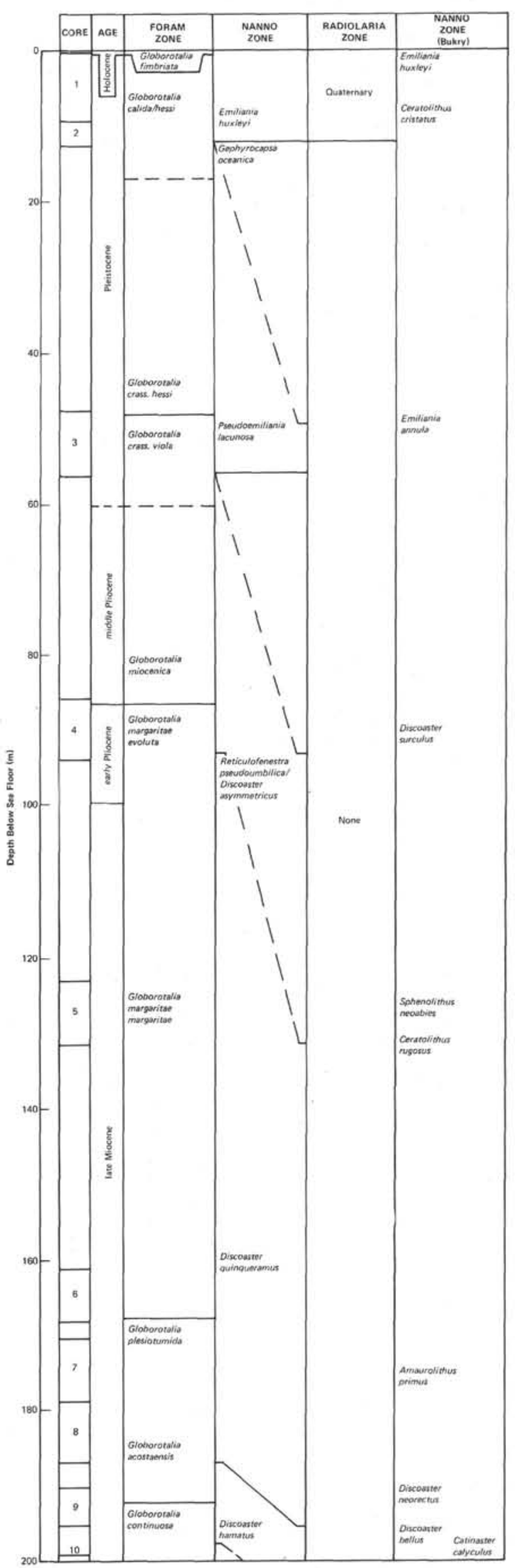

Figure 3. (Continued). 
P. ČEPEK, D. JOHNSON, V. KRASHENINNIKOV, U. PFLAUMANN

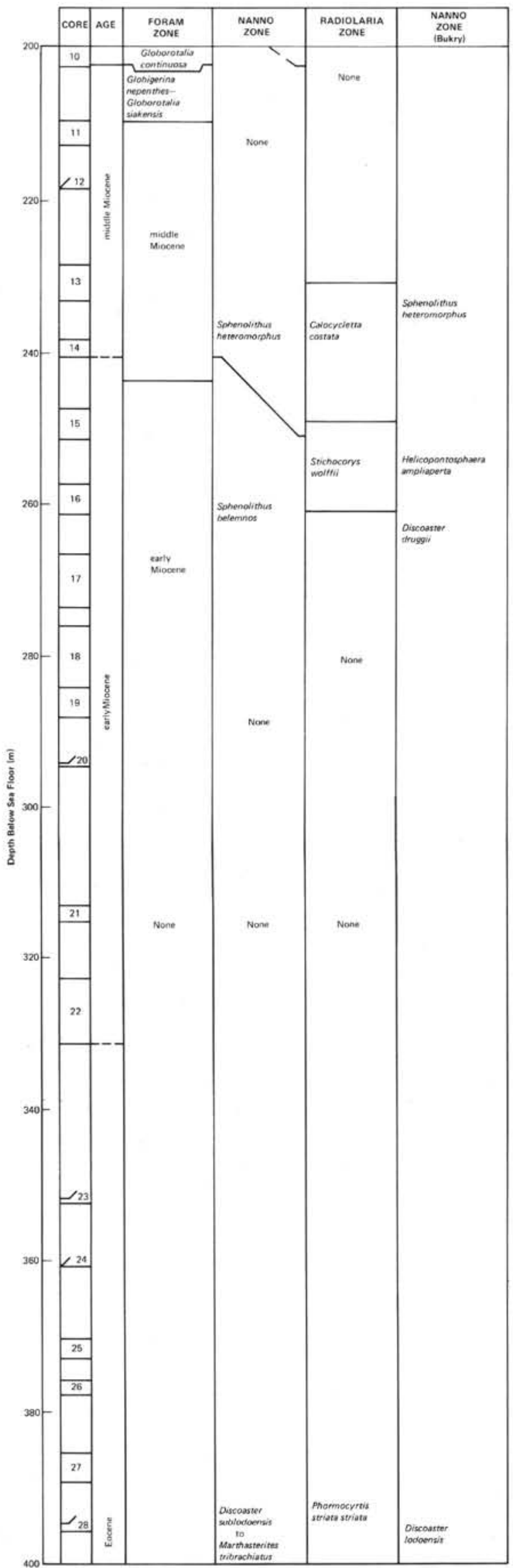

Figure 3. (Continued).

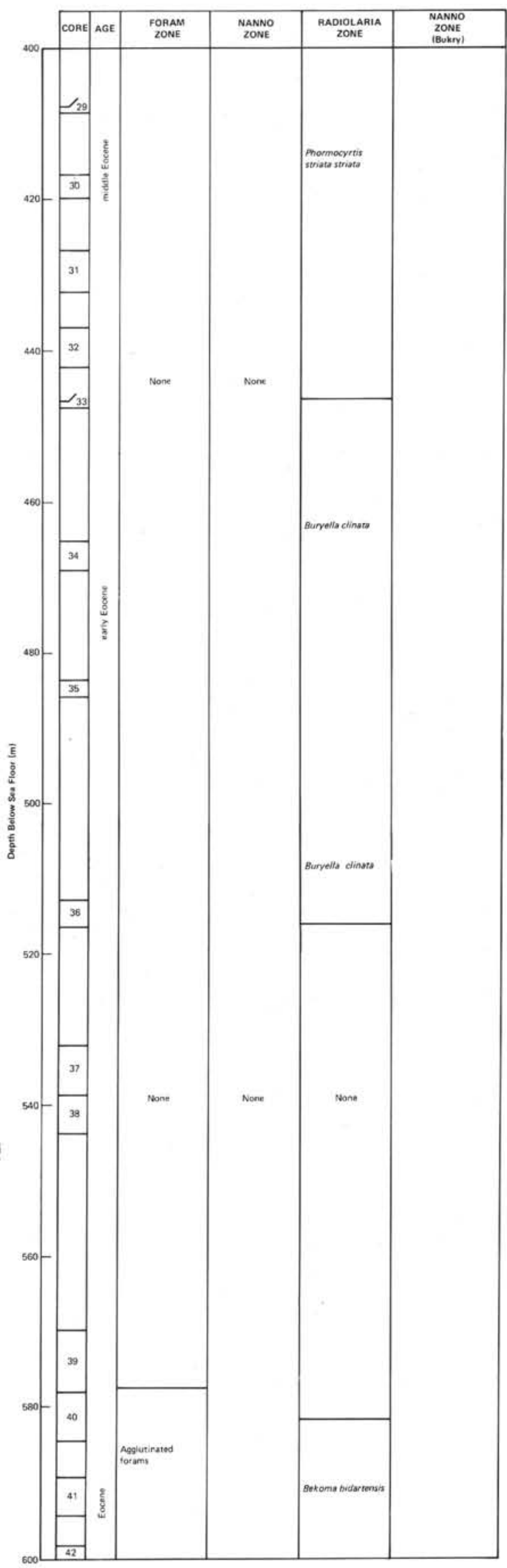

Figure 3. (Continued). 
SYNTHESIS OF BIOSTRATIGRAPHY AND PALEONTOLOGY

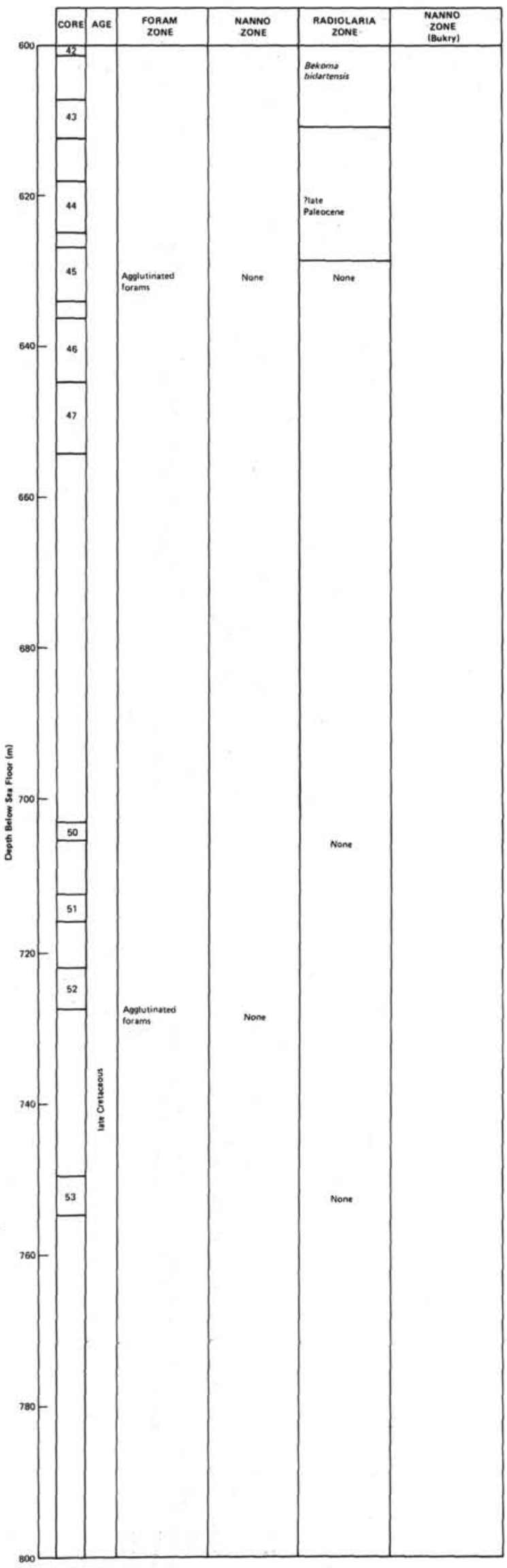

Figure 3. (Continued).

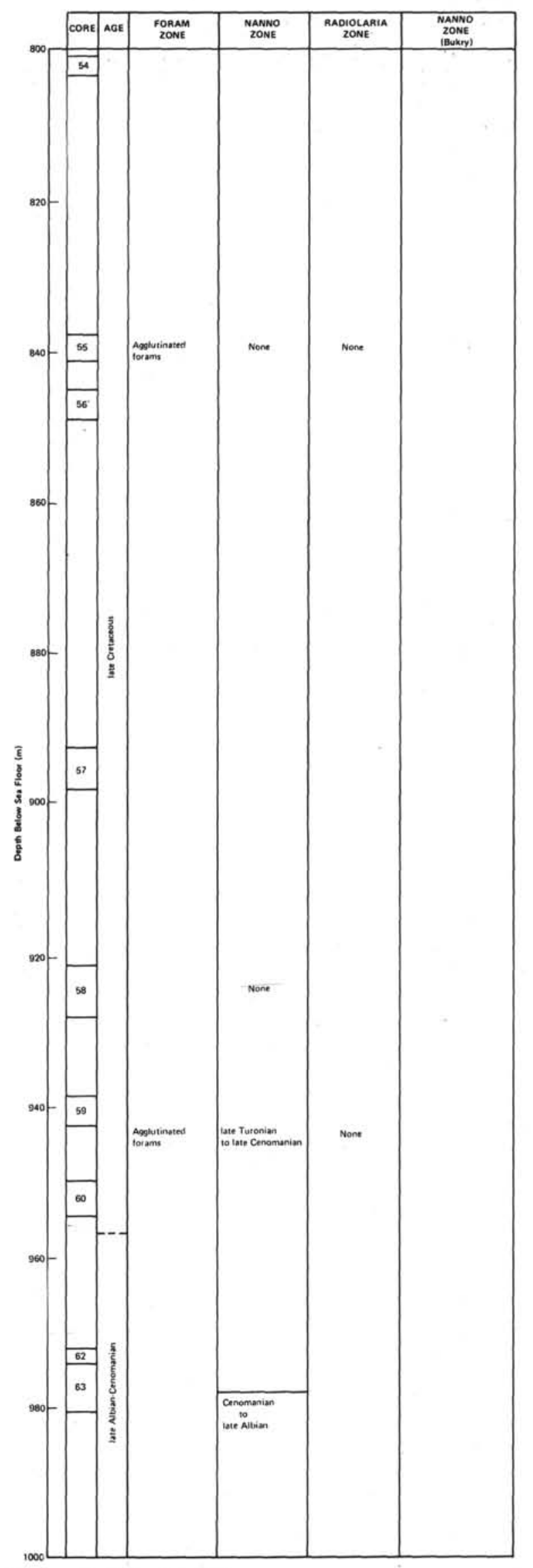

Figure 3. (Continued). 
P. ČEPEK, D. JOHNSON, V. KRASHENINNIKOV, U. PFLAUMANN

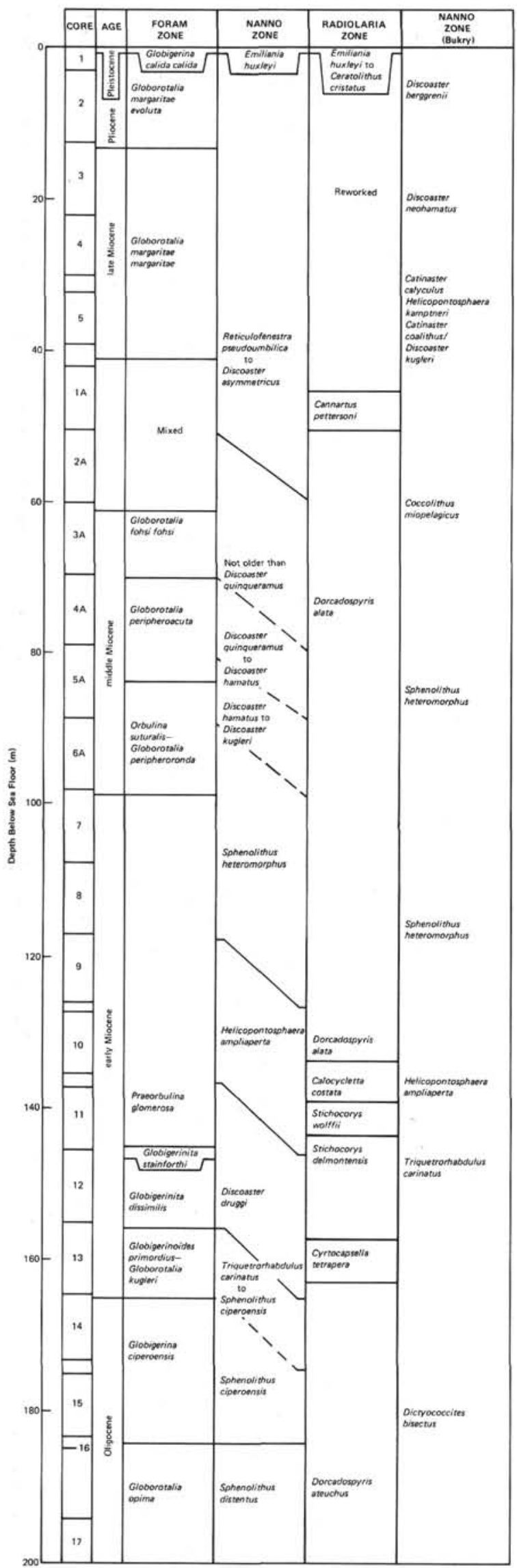

Figure 3. (Continued).

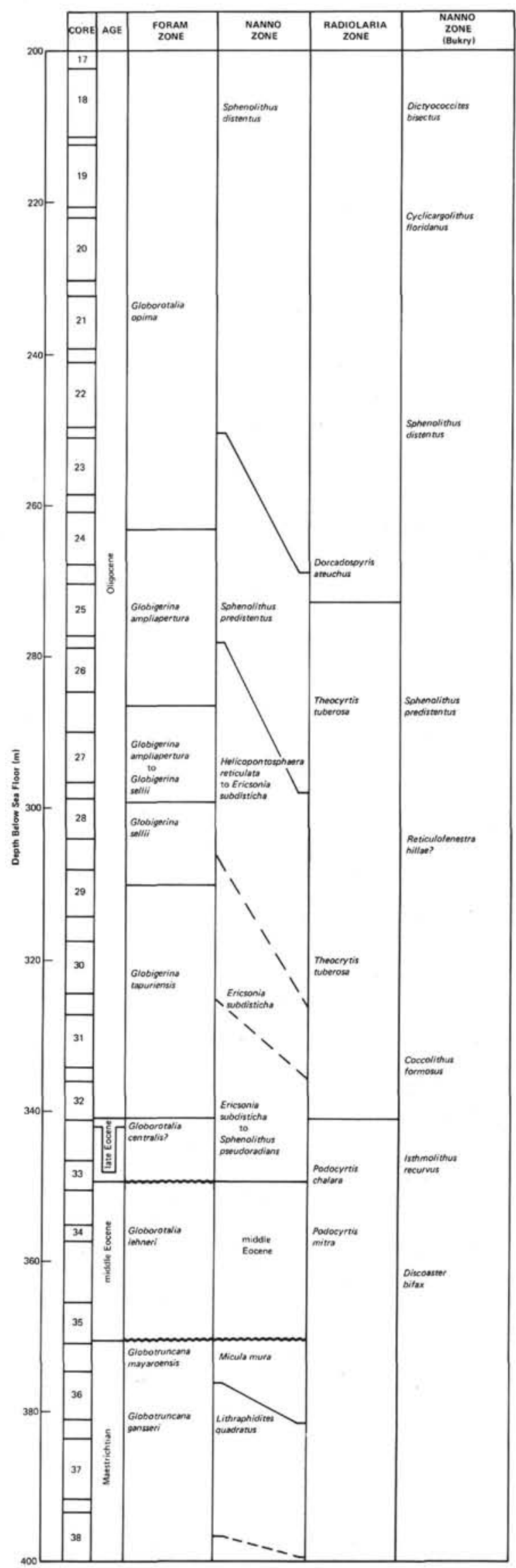

Figure 3. (Continued). 
SYNTHESIS OF BIOSTRATIGRAPHY AND PALEONTOLOGY

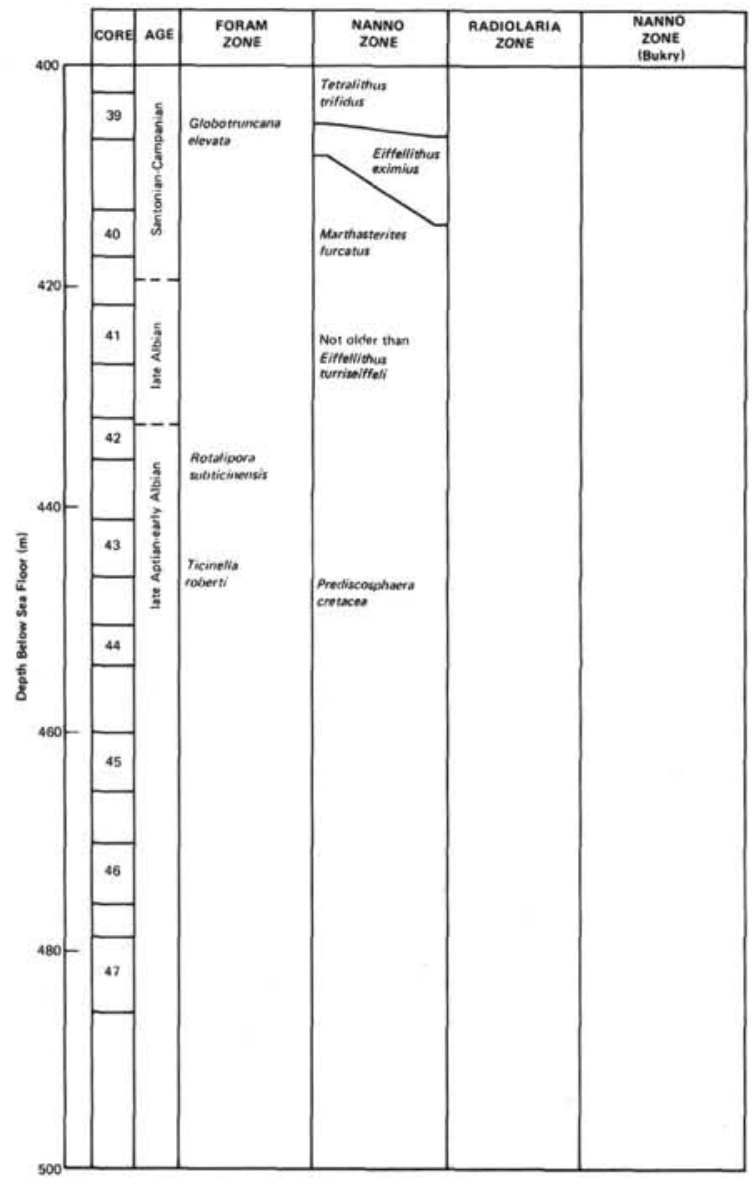

Figure 3. (Continued).

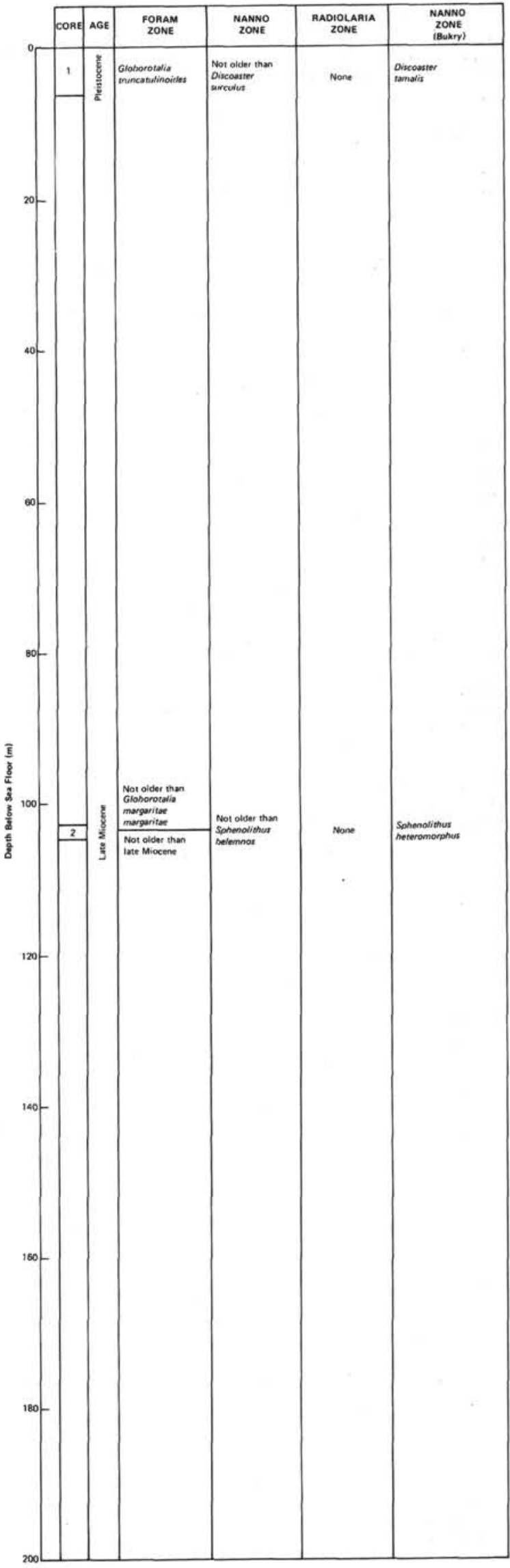

Figure 3. (Continued). 
P. ČPEK, D. JOHNSON, V. KRASHENINNIKOV, U. PFLAUMANN

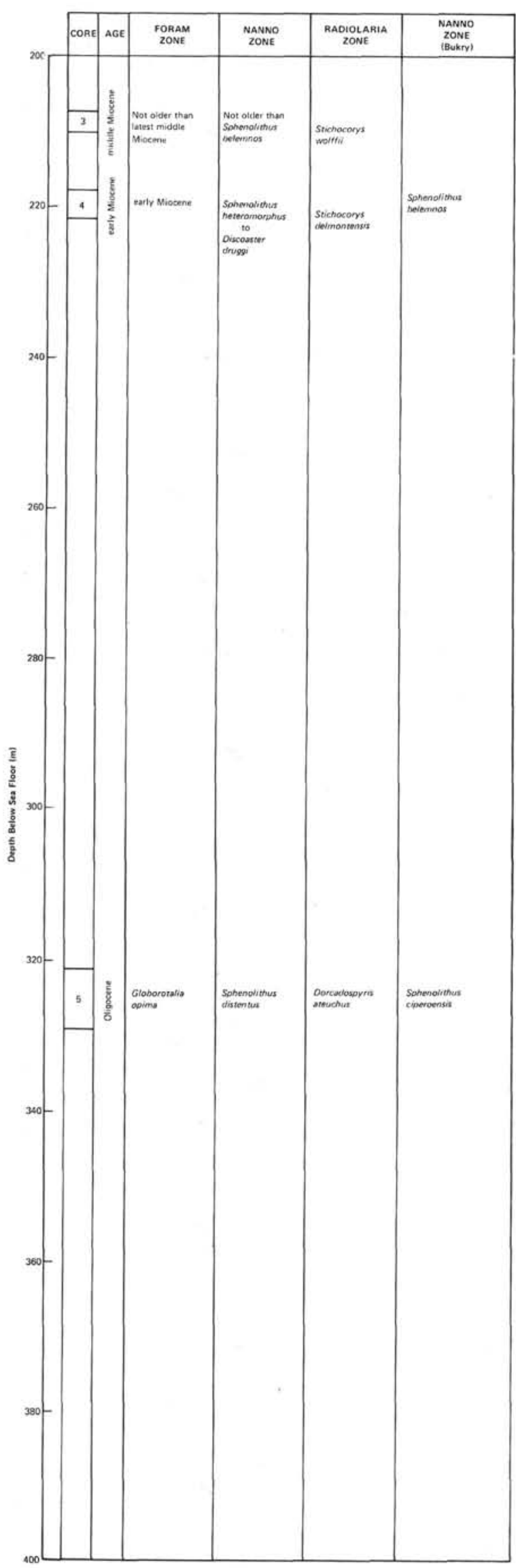

Figure 3. (Continued).

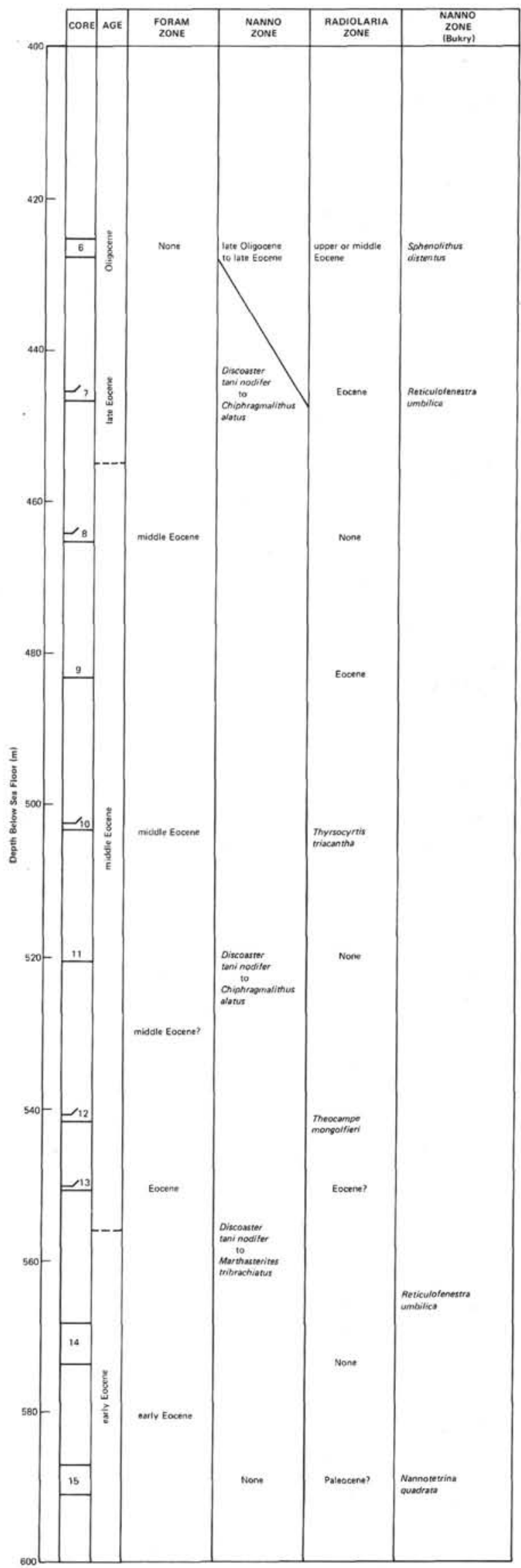

Figure 3. (Continued). 


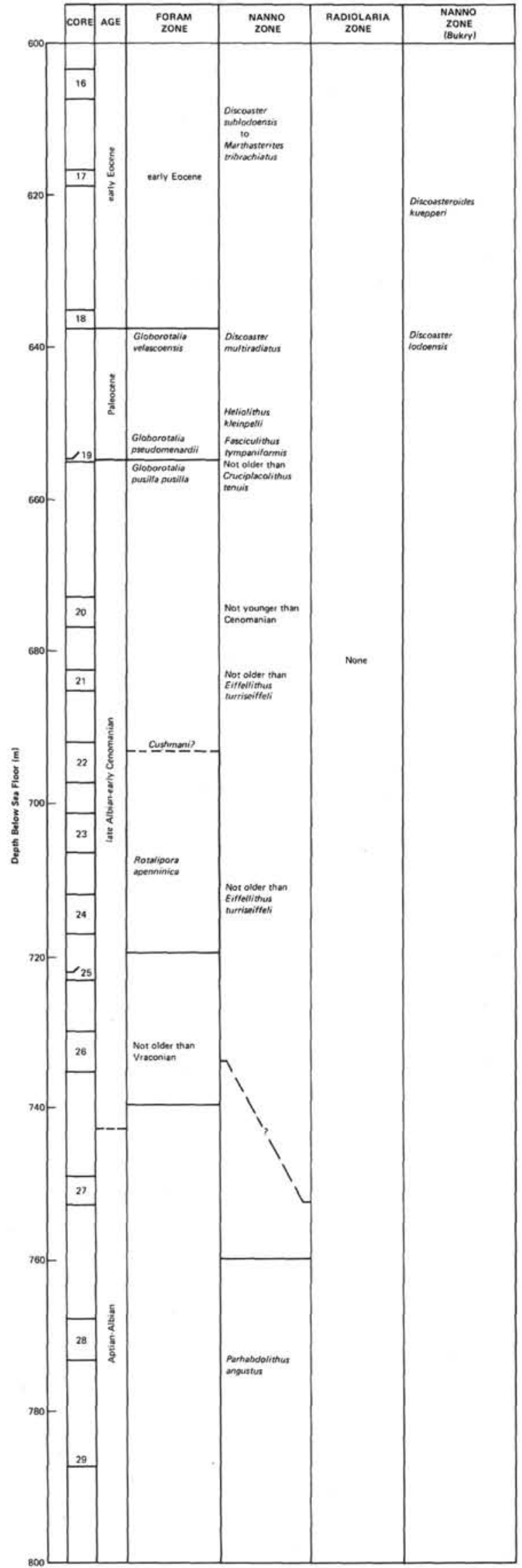

Figure 3. (Continued).

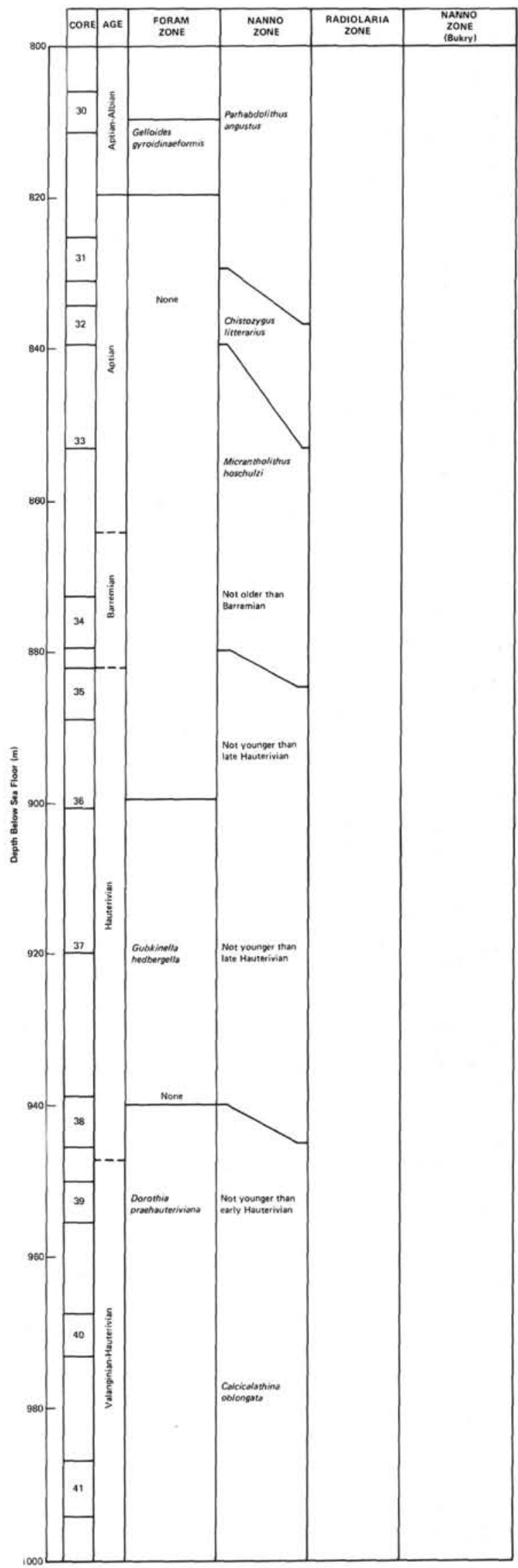

Figure 3. (Continued). 
P. ČEPEK, D. JOHNSON, V. KRASHENINNIKOV, U. PFLAUMANN

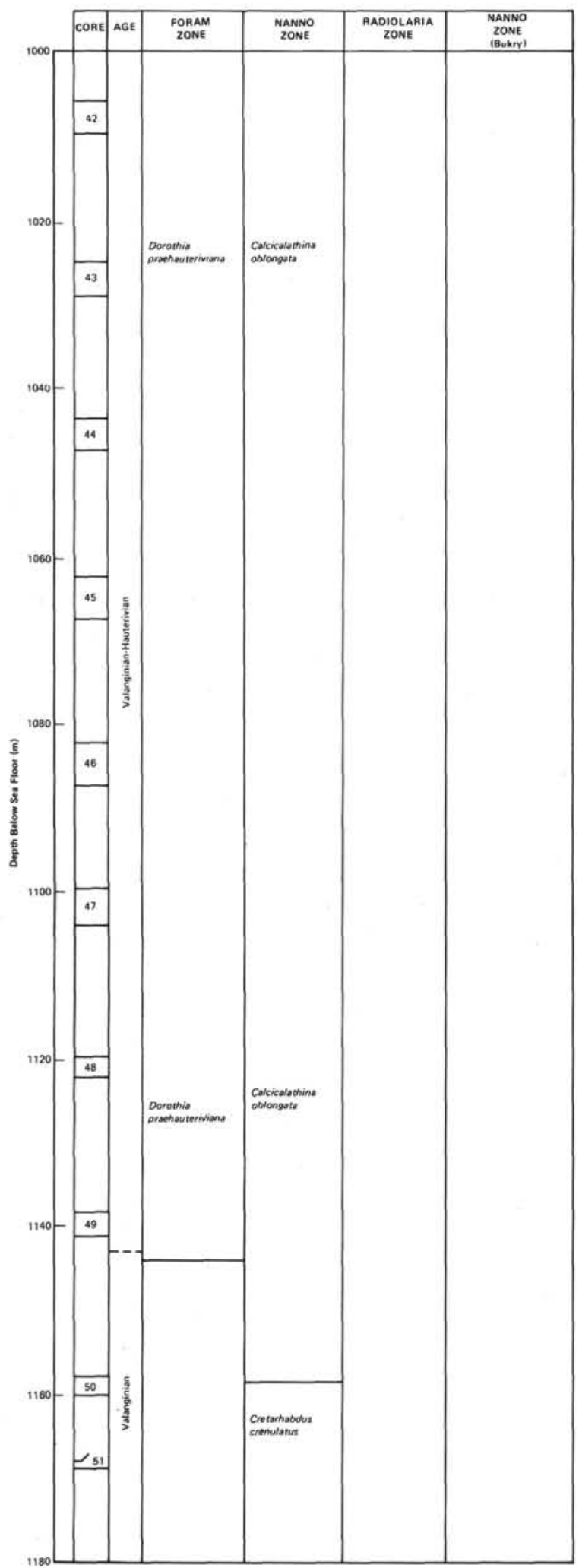

Figure 3. (Continued). 